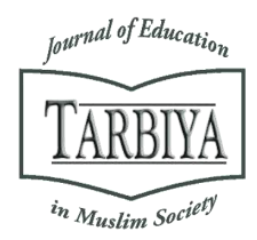

Available online at TARBIYA: Journal of Education in Muslim Society Website:

http://journal.uinjkt.ac.id/index.php/tarbiya

TARBIYA: Journal of Education in Muslim Society, 4(2), 2017, 232-239

\title{
THE CORRELATION BETWEEN EFL LEARNERS' MOTIVATION ON ENGLISH COURSE AND THEIR ENGLISH LEARNING ACHIEVEMENT
}

\author{
Dewi L. Apriliyanti, Yani Darliani \\ STKIP Pasundan, Indonesia \\ E-mail: deedeliezta@gmail.com
}

Received: $7^{\text {th }}$ September 2017; Revised: $27^{\text {th }}$ October 2017; Accepted: $28^{\text {th }}$ December 2017

\section{Abstract}

A Study has been conducted to examine the correlation between EFL learners' motivation on English course $(\mathrm{X})$ and their English learning achievement $(\mathrm{Y})$. A mixed method design used in this study. Instruments of this research were observation, questionnaire, document, and interview. Quantitative method used to measure the correlation between two variables. 30 higher students of the public school have involved in this study. The result showed that the correlation between EFL learners' motivation on English course and their English score. Even though the correlation was positive, but it was low and not significant. Meanwhile, The investigation found five explanations. First, in some cases, the method that teacher used for learning activity was not suitable with the students' condition. Second, most students felt difficulty with grammatical structure. Third, students would understand the material if they felt interesting with their teacher and materials. If they didn't feel comfortable with both of those things, they would not understand the material at all. Forth, they didn't have high curiosity because they were not remembered about the material explanation from their tutor on English course in the next day. It means that they were not learned it again at home. Fifth, $43 \%$ of students would rather to studying with their teacher at school than at English course. $36 \%$ of students would rather to studying with their teacher at courses that at school because they felt more understand learning at English course and $21 \%$ of samples were abstained.

Keywords: EFL learner; motivation; english course; UKK; English score

\section{Abstrak}

Penelitian ini dilakukan untuk menguji korelasi antara motivasi peserta didik bahasa Inggris sebagai bahasa asing (EFL) dalam mengikuti kursus bahasa Inggris (X) dan prestasi belajar bahasa Inggris mereka di sekolah (Y). Desain metode campuran digunakan dalam penelitian ini. Instrumen penelitian ini adalah observasi, kuesioner, dokumen, dan wawancara. Metode korelasi digunakan untuk mengukur hubungan antar dua variabel. 30 siswa Sekolah Menengah Atas (SMA) terlibat sebagai sampel dalam penelitian ini. Hasil penelitian menunjukan ada korelasi antara motivasi peserta didik EFL terhadap nilai bahasa Inggris mereka. Meskipun hasil menunjukan adanya hubungan yang positif namun rendah dan tidak signifikan. Hasil investigasi menemukan lima temuan. Pertama, dalam beberapa kasus, metode yang digunakan guru untuk kegatan belajar tidak sesuai dengan kondisi siswa. Kedua, kebanyakan siswa merasa kesulitan dalam memahami stuktur gramatika dalam bahasa Inggris. Ketiga, siswa akan memahami materi jika mereka merasa tertarik dengan guru dan bahan ajarnya. Jika mereka tidak merasa nyaman dengan kedua hal tersebut, merek tidak akan memahami materi sama sekali. Keempat, mereka tidak memiliki keingintahuan yang tinggi karena mereka tidak ingat penjelasan materi dari tutor mereka pada saat kursus bahasa inggris dihari berikutnya. Artinya mereka tidak mempelajarinya lagi dirumah. Kelima, 43\% siswa memilih untuk belajar dengan guru mereka disekolah, 36\% siswa memilih belajar dengan tutor di tempat kursus mereka, dan 21\% tidak memilih keduanya.

Kata kunci: peserta didik; motivasi; kursus bahasa inggris; UKK; skor bahasa Inggris

How to Cite : Apriliyanti, D. L., Darliani. Y. (2017). The Correlation Between EFL Learners' Motivation on English Course and Their English Learning Achievement. TARBIYA: Journal of Education in Muslim Society, 4(2), 232-239. doi:10.15408/tjems.v4i2.6401.

Permalink/DOI: http://dx.doi.org/10.15408/tjems.v4i1.6401 


\section{Introduction}

Learning is an activity that aims to increase the knowledge. The sources could be from the formal institution such as schools, the informal institution such as courses and the environment around the learners. Learning involves the formation of associations between sensory experiences and neutral impulses that manifest themselves behaviorally. Learning often occurs by trial and error (selecting and connecting). Language is the first knowledge that is acquired by the people. As people grown up, they need to learn other languages besides their first language for the worldwide communication such as English. English is a foreign language in Indonesia. Indonesian people need to learn English because English as a lingua-franca and as one of the most widely used foreign language in academics, politics, business, trade, and the diplomatic circle. Hence, the Indonesian government decided to make English as a foreign language that must be taught in the junior high school to the senior high school (Law no.20/2003).

Nevertheless, it cannot be denied that as foreign learners, Indonesian felt difficulties to learn English while they did not use it in daily activities. There must be a willpower in them to learning English. If learners have high motivation in learning, they will show great interest and attention in learning activities such as learning English as the foreign language and try hard to learn it (Huitt, 2007; Uno, 2008; Schunk et al., 2010). For instance, Lamb (2004) reported the research data from junior high school students in Indonesia and claimed that Indonesian students' motivation might partly be formed by the pursuit of a bi-cultural identity such as their nationality. Thus, they 'aspire to a vision of English-speaking globally-involved but nationality responsible future self (Lamb, 2004, 16). Then, Lamb (2014) argued that this reference of learning English motivation could be changing based on their perceptions and their identity while they were grown up.

\section{Learning Motivation Theories}

Motivation is an inner drive to behave. These inner conditions such as wishes, desires, and goals, activate to move in a particular direction in behavior (Reiss, 2005). Motivation is the process used to allocate energy to maximize the satisfaction of needs in which making choices about goals to pursue and the effort that devoted to that pursuit (Brown, 1994; Pritchard \& Ashwood, 2008). Maslow (1954) developed the hierarchy of needs consisting of five hierarchic classes; (1) Physiology; (2) Safety/Shelter/Health; (3) Belongingness/Love/Friendship; (4) Selfesteem/Recognition/Achievement; and (5) Selfactualization.

Freud analogized 'motivation' as 'psychical energy' that is satisfied and turned it into positive energy. The energy developed when the need is existed (Schunk et al., 2010, 19). Meanwhile, behavioral theories view motivation as " change in the rate, the frequency of occurrence, or form of behavior (response) as a function of environmental events and stimuli' (Schunk et al., 2010, 20). Behavioral theorist claimed that motivation happens not because of the needs of satisfaction but environmental events that caused motivation develop. Thus, motivation is a desire of achieving its goal of satisfaction, and its desire could be coming from either the satisfaction of needs or the environmental events.

Psychologists divided motivation as either intrinsic motivation or extrinsic motivation. Intrinsic motivation occurs from the inside of learner's oneself. Intrinsically motivated rewarding consequences, namely, feelings of competence and self-determination' (cited in Brown, 1994, 39). On the other hand, extrinsic motivation appears when learners insisted to do something or to act certain ways because of 
external factors to him or her (achieving good grades). Extrinsic motivations are rewards (grades) as the appreciation of good behavior, and punishment as the consequence of negative behavior (Reiss, 2005). However, recently, many studies revealed motivation concept as wider than that two categories (See Thorndike's Law of Motivation, Gardner's integrative motivation theory, and Dörnyei's L2 motivation selfsystem).

Thorndike formulated two laws of learning motivation, the law of effect and the law of readiness (Schunk et al, 2010). The law of effect is that 'the consequences of behavior are motivating and produce learning. Responses that result in rewarding consequence are learned, and those that produce punishing consequences are not learned' (Schunk et al., 2010, 21). Thus, punishing children for misbehaving does not weaken the misbehavior unless children were taught appropriate ways of behaving. While the law of readiness means when learners are forced to learn, and they are not ready, then the learning is useless. On the contrary, when they are ready then the learning is satisfying.

However, Gardner (2001) has a little different perspective about the law of readiness. Gardner stated that readiness was happened when the learners had interested in the foreign language such as their willingness to study abroad or their interests with intercultural partners. It was called 'integrative orientation' (Yashima, 2002). Meanwhile, integrative motivation was 'a more complex multicomponential construct, consisting of three main constitutes; integrativeness, attitude toward learning situation, and motivation' (Dörnyei et al., 2009, 23). Then, it saw as 'the driving force of motivated behavior, subsuming effort, desire, and affect' (Gardner, 2001).

Dörnyei et al., created the formulation of 'L2 motivation self-system'. Dörnyei et al., argued that 'the central theme of the emerging new theory was the equation of the motivational dimension that has traditionally been interpreted as 'integrativeness or integrative motivation' with the ideal L2 self (Dörnyei et al., 2009, 27). It formulated then two main important factors in which developed the ideal L2 self; Attitude toward members of the L2 community and instrumentally in long-term motivation (ideal self-guided to have promotion focus and accomplishment) and short-term motivation (ought-to self-guided such as having good grades) (Dörnyei et al., 2009). Thus, regarding learning English as a foreign language in Indonesia, first, the learners should have the motivation to learn English and then make some effort to achieve their goal in the learning.

\section{English Course}

The course is a teaching and learning activities as well as schools. The difference is that the courses are usually held in a short time and only to learn one skill (Marzuki, 2010). There are many advantages for learners who are attending private tutoring or specific course program; improving children's academic ability, customizable learning time, easy to monitor, helping parents who do not have time, facilitating the children in the study, making new friends.

There are also disadvantages for children who are attending private tutoring or course program; (1) Extra pocket; learners requested extra pocket money for transportation or other reasons. (2) If the children are too tired, they tended to misfocus while teaching and learning session.

There were several studies that have various results in which related to learning motivation and English subject achievement score (e.g., Li \& Pan (2009), Lisa (2012), Lasagabaster (2011), \& Jeon-Yeon (2014)). Li \& Pan (2009) investigated the relationship between motivation and achievement among the 
students of English majors in one of the universities in China while Lisa (2012) investigated the similar issues in Indonesia and Lasagabaster (2011) in the Basque country. The result of the investigation showed that motivation plays an important role in English majors' learning' and higher achievers have the higher sense of achievement motivation and the learners who have high motivation in learning English will get better grades than those who have low motivation in learning English. However, Jeon-Yeon (2014) revealed that motivation had not directly correlated with the learning achievement after the investigation about the role of English-medium instruction policy. Jeon-Yeon (2014) stated that motivation was not enough; the instruction was needed while the learning process.

Based on the theories and the evidence above, it concluded that the motivation is the important variable in learning the foreign language even though several studies argued about it. Though, this issue is still interesting to be studied, but a small number of researches in which discussed this issues interrelated with English courses. Thus, this study would focus on the learners' motivation of learning English and the effect of their attendance in English courses on their English learning achievement at school.

\section{Hypothesis}

There is a significant correlation between students' motivation on English course and their English learning achievement.

\section{Methods}

This study was using explanatory mix method with correlational design as the primary of this study. There are two variables in this study. Learners' motivation to attend on English course as the independent variable and English learning achievement through final term examination as the dependent variable. Thirty tenth-grade students of one public school in Cimahi were involved in this study. The name of students was replaced by using the students' identity number (Std. No, e.g., 001, etc.,) for the privacy. They attended on English course for about 6 month-1 years. The instruments were documentation, questionnaire, and interview. School documentation was used to get learners' achievement in final English examination in term one. The questionnaire consists of 20 statements by using the Likert scale -1 for strongly disagree to 5 for strongly agree. The data was analyzed by using correlation coefficient. Then, the semi-structured interview was held with the learners to investigate deeper information based on the quantitative analysis.

Table 1. Operational of research variables

\begin{tabular}{|c|c|c|c|}
\hline Variable & $\begin{array}{l}\text { Dimensio } \\
\mathbf{n}\end{array}$ & Indicator & $\begin{array}{l}\text { Items of } \\
\text { Questio } \\
\text { nnaire }\end{array}$ \\
\hline \multirow[t]{3}{*}{$\begin{array}{l}\text { Motivatio } \\
\mathrm{n} \text { on } \\
\text { English } \\
\text { Course } \\
(\mathrm{X})\end{array}$} & $\begin{array}{l}\text { Intrinsic } \\
\text { Motivatio } \\
\mathrm{n}\end{array}$ & $\begin{array}{lc}1 . & \text { Self- } \\
\text { determination } \\
2 . \quad \text { Self- } \\
\text { actualization } \\
\text { 3. } \quad \text { Self-efficacy }\end{array}$ & $\begin{array}{l}1,4,19, \\
20 \\
13,14 \\
2,6,12, \\
15\end{array}$ \\
\hline & $\begin{array}{l}\text { Extrinsic } \\
\text { Motivatio } \\
\text { n }\end{array}$ & 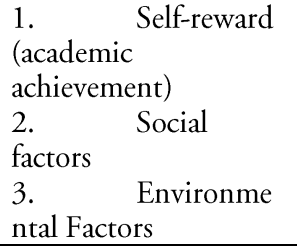 & $\begin{array}{l}3,5 \\
10,11, \\
16,17 \\
8\end{array}$ \\
\hline & $\begin{array}{l}\text { Enhance } \\
\text { cognitive } \\
\text { processing }\end{array}$ & $\begin{array}{l}\text { Method and } \\
\text { technique }\end{array}$ & $7,9,18$ \\
\hline $\begin{array}{l}\text { English } \\
\text { Score }(Y)\end{array}$ & $\begin{array}{l}\text { Final } \\
\text { examinati } \\
\text { on (UKK) }\end{array}$ & $\begin{array}{l}\text { Low and high } \\
\text { achievement }\end{array}$ & - \\
\hline
\end{tabular}

\section{Result and Discussion}

\section{Results}

\section{Quantitative: Validity}

The instrument validity test was using the Point Biseral technique. From 20 items of questionnaire, there were 16 items of questionnaire which was valid -item number $1,5,6,7,8,9,10,12,13,14,15,16,17,18,19$ and 20 . 
Meanwhile, four items got the $r$ score less than $r$ table (0.36). The invalid items were items number 2, 3, 4, and 11 .

\section{Reliability}

The reliability test was using the Alpha Cronbach technique. The result was 0.882891226 . That result was bigger than 0.80 (The standard of the reliability test). It means that the questionnaire was reliable to be testedwith eliminated items number 2, 3, 4, and 11for this research.

Table 2. Reliability Statistics

\begin{tabular}{lllll}
\hline Cronbach's Alpha & \multicolumn{3}{c}{ N of Items } \\
\hline .883 & \multicolumn{4}{c}{16} \\
\hline \multicolumn{5}{c}{ Table 3. The Frequency Distribution of Learners' } \\
motivation on English course \\
Learners' Motivation \\
Scale- & $\mathbf{F}$ & $\mathbf{F k}$ & $\mathbf{X i}$ & $\mathbf{f .} \mathbf{x i}$ \\
Score & & & & \\
$46-53$ & 1 & 1 & 49,5 & 49.5 \\
$54-60$ & 0 & 1 & 57 & 0 \\
$61-67$ & 3 & 4 & 64 & 192 \\
$68-74$ & 5 & 9 & 71 & 355 \\
$75-81$ & 12 & 21 & 78 & 936 \\
$82-88$ & 9 & 30 & 85 & 765 \\
Total & 30 & & & 2297.5
\end{tabular}

The average of formula $\mathrm{x}=\sum$ f. $\mathrm{xi}=$ $\underline{2297.5}=76.583 \quad \sum f \quad 30$

Based on the calculation by using formula $x$, it showed that learners' motivation on English course was high. Only four of the sample who have lower motivation.

Table 4. Correlations

\begin{tabular}{llll}
\hline & & Motivation & Achievement \\
\hline Motivation & Pearson & 1 & .276 \\
& Correlation & & \\
& Sig. (2-tailed) & & .139 \\
& $\mathrm{~N}$ & 30 & 30 \\
Achievement & Pearson & .276 & 1 \\
& Correlation & & \\
& Sig. (2-tailed) & .139 & \\
& $\mathrm{~N}$ & 30 & 30 \\
\hline
\end{tabular}

Based on the result of the correlation coefficient above, there are $\mathrm{r}$ value $=0.276$ and $\mathrm{t}$ value $=1.519$. It is compared with $\mathrm{n}=30$, with mistake level $5 \%$, and $\mathrm{df}=\mathrm{n}-2=30-2=28$. So, $\mathrm{t}-$ table $=2.048 . \mathrm{T}$-value is lower than $\mathrm{t}$-table $(1.519<2.048)$. In connection with $r$ value $\neq 0$, so, $\mathrm{Ha}$ is rejected and there is a low correlation between students' motivation on English course and their English score.

Based on the computation ( $r$ ) and testing for the significance, the conclusion was as follow: (1) There was correlation between students' motivation on English course and their English learning achievement, (2) Though the correlation was positive, but it was low and insignificance.

\section{Qualitative}

From the investigation, it revealed four evidence. First, learning on course was favorable for most of the learners. Most of the learners assumed that learning on courses was fun, comfortable, relax, and more detail in material explanation than at school. R005 said “... It's fun ... I felt more understand study on course than at school". R006 argued "learning on course was fun and I understood the materials, while at school was so serious, and I did not enjoy". R011 said "according to me, learning on courses was time efficiency. I felt more comfortable learning on course than at school. Because the students at class was so many (big class) that I could not be focused learning at school. While on course was small class so that it was not too crowded for learning. I just enjoy study on course".

Second, most of them claimed that the tutor taught them very well and they understood with the material explanations, but they forgot about the material explanation in the next day. As R018 stated "I improved a little but I was easy to forget, such as I learned A at that day 
then in the next day I forgot what I've learned before"

Third, the reason of why they have a lower score of examination were teaching methods, kind of materials, and depend on the teachers at school. First, in some cases, the method that teacher used for learning activity is not suitable for the learners' circumstances. As R011 said, "I was bored with the method (at school)." Second, most learners were felt difficult with grammatical structure. R005 "I am confused in learning grammatical structure." The last one, learners would understand the material if they felt interesting with their teacher and materials. If they didn't feel comfortable, they would not understand the material at all, and it would be effected with answering the UKK examination. $43 \%$ of students would rather to studying with their teacher at school than at English course. One of the reasons was the teacher at school taught them with full English, and it was motivated them to learn English more at English course. $36 \%$ of students would rather to studying with their tutor at courses that at school because they felt more understand learning at English course and $21 \%$ of samples abstained.

\section{Discussion}

The foregoing researches, for instance Pan (2009), Lisa (2012), and Lasagabaster (2011), found that motivation plays an important role in English learning. However, this study showed that the effect of motivation on course to English learning achievement only around $28 \%$. It means that around $72 \%$ comes from other factors that have effects on learners' achievement.

The researcher tried to looking for other factors that "may" affect the learners' achievement as follow;

Firstly, being motivated is not enough because motivation is an inner drive to behave or act in certain manners (Kelley, 2010; Kent,
2014; Arain, 2014). The motivation should be followed by actions that were referred to a particular purpose -in this case the grade of UKK. The learners attended on English course as an action to improve their achievement.

Secondly, in this case, students were not satisfied with their score of UKK so they were motivated to get more than their achievement. Maslow's need theories mentioned that only unsatisfied needs influence behavior, satisfied needs do not (Kaur, 2013). It means that if students were satisfied with their grade -although they got the relative low achievement- the motivation on course would not has a significant impact on its achievement at school.

Thirdly, only being motivated was not enough, but it should be engaged with real action and high curiosity with the material that is taught on course or material that would be tested on the UKK (Reiss, 2005). That was the problem. Even though, the students have a real action to attend on English course but they didn't have high curiosity because they were forgot about the material explanation from their tutor on English course in the next day. It means that they were not learned it again at home.

Learners were not always internally motivated. They also need situated motivation of which was found in environmental conditions that teachers created in the classroom. 'We often see the reflection of the students' motivation and personal investment in the engagement of cognitive, emotional, and various behavioral activities in school' (Fredricks, Blumenfeld, \& Paris, 2004; Maehr \& Meyer, 2004; Reeve 2006, Cited in Ormrod, 2008:58). It means that even though the situation in which was created on English course could motivate students in learning English, nevertheless, when they were in the school (class) situation that was created by the teacher could not make students motivated to try more active in learning and to understand the English language material. Teachers at school 
have a substantial role to help the learners driven their motivation into a real effort to improve their achievement.

\section{Conclusion}

This study concludes that motivation is a good basis for learning but being motivated to reach a goal is not enough. It must be followed by real action, willing to practice and have high curiosity to learn more. The investigation revealed that the reason of why learners have a lower achievement in UKK than they expected because of teaching methods, kind of materials, and depend on the teachers' personality. The researcher evaluated that this study only focused on students' perception and it will be better if the further research could see the tutor's, teacher's perception and could do classroom observation to get the deeper result.

\section{References}

Arain, M. S. (2014). Woman Police Unfurled in Pakistan: Perspective, Status, and Prospective. Pakistan: Lulu Publisher. ISBN: 131227624X, 9781312276246.

Brown, H.D. (1994). Teaching by Principle: An Interactive Approach to Language Pedagogy. New Jersey: Prentice Hall Regents.

Deci, E.L. \& Ryan. R.M. (1980). The empirical exploration of intrinsic motivation processes. In L. Berkowitz (Ed.), Advances in experimental social psychology. 13, (3980). New York: Academic Press.

Dörnyei, Z. (2001). Motivational Strategies in the Language Classroom. UK: Cambridge University Press.

Dörnyei, Z. \& Ushioda, E. (2009). Motivation, Language Identity and the L2 Self. UK: Multilingual Matters.

Huitt, W. (2007). Maslow's Hierarchy of Needs. Educational Psychology Interactive. Valdosta, GA: Valdosta State University.
Gardner, R. C. (2001). Integrative Motivation and Second Language Acquisition. In Dörnyei, Z. \& Schmidt. (Eds). Motivation and Second Language Acquisition, pp.120. Honolulu, HI: University of Hawaii Press.

Jeon-Yeon, K. (2014). College EFL Learners' Speaking Motivation under EnglishMedium Instruction Policy. Journal of ASIA TEFL. 11(1), pp. 37-64.

Kaur, A. (2013). Maslow's Need Hierarchy Theory: Applications and Criticisms. In Global Journal of Management and Business Studies. Vol. 3 (10), pp. 10611064. India: Research Indiana Publications

Kelley, R. C. (2010). Relationships. Indianapolis: Dog Ear Publishing.

Kent, K. (2014). Living 365fitt: A 12 WeekProgram to Lifestyle Wellness. ISBN: 9781-304-84010-3.

Lamb, M. (2004), March 1. Integrative Motivation in a Globalizing World. Retrieved from http://eprints.whiterose.ac.uk/1655/1/lam bm1_System_revised1.pdf

Lasagabaster, D. (2011). English Achievement and Student Motivation in CLIL and EFL Setting. Innovation in Language Learning and Teaching. 5 (1), 3-18.

Li, P. \& Pan, G. (2009). The Relationship between Motivation and Achievement: A Survey of the Study Motivation of English Majors in Qingdao Agricultural University. In English Language Teaching Journal. 2 (1), 123-128.

Lisa, K. 2009. The Correlation between Students' Motivation in Learning English and their Speaking Achievement. Unpublished Skripsi. Jakarta: UIN Syahid.

Maslow, A. (1954). Motivation and Personality. New York: Harper.

Marzuki, Saleh. H.M. 2010. Pendidikan Nonformal: Dimensi dalam Keaksaraan Fungsional, Pelatihan, dan Andragogi. Bandung: Penerbit Rosda. 
Ormrod, J. E. (2008). Human Learning (fifth edition). Upper Saddle River, NJ: Pearson Merrill Prentice Hall.

Pritchard, R. \& Ashwood, E. (2008). Managing Motivation. New York: Taylor \& Francis Group. p. 6. ISBN 978-1-84169-789-5.

Reiss, S. (2005). Extrinsic and Intrinsic Motivation at 30: Unresolved Scientific Issues. In The Behavior Analyst. 28, 1-14.

Schunk, D. H., Pintrich, P. R. \& Meece, J. L. (2010). Motivation in Education: Theory, Research, and Applications, $3^{\text {rd }}$ edition. London: Pearson Education.
Ushioda, E. (2006). Motivation, autonomy and sociocultural theory. In P. Benson (Ed.), Learner autonomy 8: Insider perspectives on autonomy in language learning and teaching. (5-24). Dublin: Authentik.

Yashima, T. (2002). Willingness to communicate in a second language: The Japanese EFL context. The Modern Language Journal, 86, pp. 54-66. Indonesian Law, No. 20, 2003 